\title{
Chapter 18 \\ The Adaptation M\&E Navigator: A Decision \\ Support Tool for the Selection of Suitable \\ Approaches to Monitor and Evaluate Adaptation to Climate Change
}

\section{Timo Leiter}

\begin{abstract}
With increasing implementation of climate change adaptation policies and projects as well as continued integration of adaptation into planning processes, there is an increasing need to understand the results of these adaptation interventions. Are they achieving their objectives? Are they actually leading to a reduction in vulnerability to climate change?

Monitoring and evaluation (M\&E) can help answer these questions. However, due to the context specific and cross-sectoral nature of adaptation there is no one-size fits all approach to M\&E. The Adaptation M\&E Navigator helps to select a suitable $M \& E$ approach by providing a list of specific $M \& E$ purposes and matching them to relevant approaches. Key characteristics of each approach are highlighted to enable informed decision making. The Adaptation M\&E Navigator also provides links to further guidance and examples from practice. The chapter outlines the rational and structure of the Adaptation M\&E Navigator and how it can be used in practice.
\end{abstract}

Keywords Adaptation - Monitoring and evaluation $\bullet$ M\&E approach • Adaptation outcomes $•$ Adaptation process

\subsection{Introduction}

Preparing for and adjusting to the impacts of climate change through planning, capacity building and adaptation actions is taking place at all levels, on all continents and to an increasing extent (Mimura et al. 2014). According to the 2015 Global Climate Legislation Study, more than 60 countries have frameworks in place for adapting to the impacts of climate change (Nachmany et al. 2015).

\footnotetext{
T. Leiter $(\bowtie)$

Climate Change and Climate Policy Group, Deutsche Gesellschaft für Internationale

Zusammenarbeit (GIZ) GmbH, Eschborn, Germany

e-mail: Timo.Leiter@giz.de
} 
Bilateral and multilateral climate-related finance to developing countries explicitly targeting adaptation to climate change reached USD 10 billion in 2013 (OECDDAC 2015). The continuous integration of adaptation into planning processes and the technical and financial support to developing countries have resulted in hundreds of adaptation projects around the globe. This leaves decision makers, fund managers and project implementers with the question of what is being achieved. What are the results of all these adaptation interventions? Do they lead to a reduction in vulnerability? How can the outcomes of adaptation be assessed?

Addressing this need, several frameworks and guidebooks for Monitoring and Evaluation (M\&E) of adaptation have been developed covering the project or community level (CARE 2012; Olivier et al. 2013; Pringle 2011), the national level (Ford et al. 2013; Price-Kelly et al. 2015; Hammil et al. 2014a) or multiple levels (Brooks et al. 2011; Leiter 2015). An overview of 22 publications and guidebooks for adaptation M\&E has been compiled by Bours et al. (2014a).

The increasing number of frameworks and tools for adaptation M\&E makes it difficult for decision makers and their advisors to quickly identify an appropriate one that matches their needs. In the field of climate change vulnerability and impact assessment, which is faced with an even greater proliferation of methods and tools, the PROVIA guidance has made an attempt to structure the selection process through decision trees (PROVIA 2013). Whilst the PROVIA guidance provides a useful overview of adaptation $M \& E$ literature, the proposed decision tree for $M \& E$ focuses on the project level only and consists of rather general questions (e.g. "Have you considered who else needs to be involved in the evaluation?") (PROVIA 2013, p. 52). It is also focusing more on evaluation than on ongoing monitoring and prescribes the use of indicators, which excludes other relevant $M \& E$ approaches from the start, including those based on qualitative information. Overall, the PROVIA guidance does not comprehensively identify the breath of specific reasons to engage in $M \& E$ of adaptation and does not directly indicate applicable M\&E approaches for each of them. Fisher et al. (2015) provide an extensive list of methodologies of potential use for adaptation M\&E. Yet, apart from assessing their applicability to simple, complicated or complex interventions they do not link them to initial reasons for undertaking monitoring and evaluation of adaptation.

In fact, decision makers typically encounter $M \& E$ in regard to a specific reason or information need such as finding out whether the implementation of an adaptation plan is advancing, or whether a community is better equipped to dealing with climate change impacts as result of an adaptation intervention. Such specific purposes for $M \& E$ therefore provide a logical starting point to guide the selection of $M \& E$ approaches. Hence, the Adaptation M\&E Navigator is structured along specific purposes for undertaking adaptation $M \& E$ and matches them to relevant M\&E approaches. A short description including benefits and limitations, resources needed for implementation, practical examples and links to further guidance is provided for each approach to facilitate decision-making. The sequence of steps in selecting a suitable M\&E approach and the scope of the Adaptation M\&E Navigator are shown in Fig. 18.1. The following part of this chapter outlines the content 


\section{Context in which the Adaptation M\&E Navigator is applied}

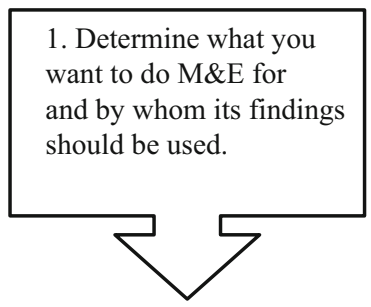

Apply the Adaptation M\&E Navigator

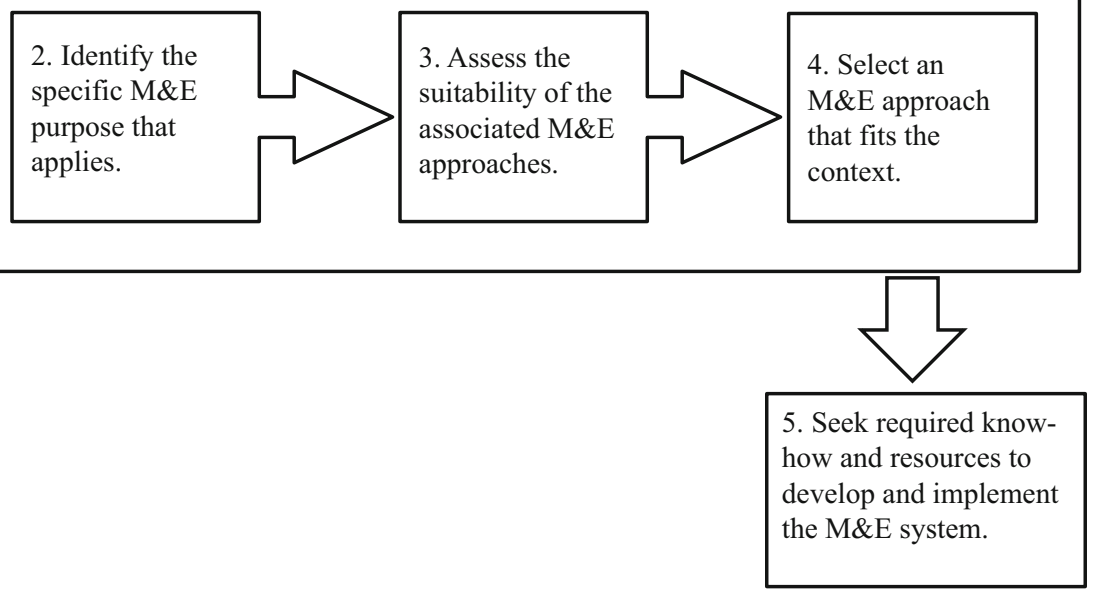

Fig. 18.1 Steps in selecting a suitable M\&E approach for adaptation

and structure of the Adaptation M\&E Navigator, its limitations and how it can be used in practice.

\subsection{Specific Purposes for M\&E of Adaptation to Climate Change}

The literature identifies a number of general purposes for monitoring and evaluating adaptation interventions, including: assessing whether they are achieving their objectives; supporting management under uncertainty; facilitating learning; and providing accountability (e.g. Pringle 2011; PROVIA 2013; Spearman and McGray 2011). However, decision makers typically encounter the need for M\&E of adaptation in light of more particular reasons. Based on a literature review (including amongst others the resources listed in Bours et al. 2014a) and the author's experience in supporting the development of national and sub-national adaptation $M \& E$ 
systems an initial list of specific purposes for adaptation M\&E was drafted. These specific purposes are universally formulated to ensure broad applicability and to avoid an unmanageable number of individual cases. The initial list was sent for comments to adaptation and M\&E experts, including selected participants of the 2nd International Conference on Evaluating Climate Change and Development. The resulting list includes nine specific purposes for adaptation $\mathbf{M} \& \mathbf{E}$ which are categorised into process or outcome-oriented assessments:

- Assessing adaptation processes

- Monitoring the integration of adaptation into planning processes

- Monitoring the implementation of adaptation programmes, projects or actions

- Monitoring the implementation of the National Adaptation Plan (NAP) process

- Tracking which adaptation activities are taking place at national or sub-national level

\section{- Assessing adaptation outcomes}

- Assessing the results of adaptation projects or actions

- Assessing the results of a programme or portfolio of adaptation projects

- Assessing whether vulnerability has been reduced as a result of adaptation programmes, projects or actions

- Assessing progress towards adaptation goals, targets or intended outcomes at national level

- Assessing whether resilience to climate change has been improved at national level

These nine specific purposes are examples of common reasons for undertaking adaptation $\mathrm{M} \& \mathrm{E}$ - either during or after the implementation of an intervention. The Adaptation M\&E Navigator does not, however, include consideration of assessments that typically take place before implementation starts such as identifying climate change impacts and appraising adaptation options (e.g. PROVIA 2013). An exception is the assessment of vulnerability at the start of an intervention if its purpose is to measure adaptation progress over time (e.g. Fritzsche et al. 2014, pp. 155-163). The Adaptation M\&E Navigator does not cover tracking financial flows for adaptation (see for example Terpstra and Peterson-Carvalho 2015).

\subsection{Connecting the Specific Purposes to Suitable M\&E Approaches}

The specific purposes for adaptation M\&E outlined above differ in regard to what is being monitored or evaluated, at what level, over shorter or longer time periods and whether the focus is on processes or outcomes. Accordingly, each of the specific 
purposes has different requirements for M\&E which makes it possible to preselect M\&E approaches that meet those requirements. For example, monitoring the integration of adaptation into planning processes does not require complex statistical analysis. Rather, a qualitative or quantitative approach focusing on the planning processes and involving stakeholders seems more suitable. It could take the form of interviews with key informants or of a set of indicators illustrating progress. This example demonstrates that there is still a variety of possible $M \& E$ approaches even for the same specific M\&E purpose. Therefore, the Adaptation M\&E Navigator does not lead users to the one and only $M \& E$ approach, but rather directs them to a short list of relevant M\&E approaches. Indeed, the Adaptation M\&E Navigator helps to filter among the many existing M\&E approaches those that seem most relevant for a given purpose.

The M\&E approaches which are associated with the same specific purpose each constitute a very distinctive way of assessment, e.g. assessing improvements in resilience through either a set of high level national indicators or through household level questions as part of a census (Welle et al. 2014). Every M\&E approach can in turn be implemented in a variety of ways. For example, the exact interview procedures, number and composition of interviewees of the M\&E approach "Qualitative assessment based on interviews" can vary greatly. In fact, the final M\&E design is typically tailored to the specific context, as demonstrated by the M\&E methodology of the United Kingdom's capacity building support to help implement Ethiopia's Climate-Resilient Green Economy Strategy described in Adler et al. (2015). The Adaptation M\&E Navigator is supporting decision makers and their technical advisors to identify a suitable M\&E approach which can then be tailored to the particular context.

\subsection{Supporting the Selection of a Suitable M\&E Approach}

The suitability or appropriateness of a particular M\&E approach can only be determined in light of the specific context of application. The Adaptation M\&E Navigator includes five criteria which are useful to consider:

1. The main intention or general purpose the $M \& E$ approach is mainly catering to, i.e. learning, management or accountability

2. A focus on process or outcome-orientation

3. The degree of complexity of implementing the $M \& E$ approach

4. The degree of subjectivity of the M\&E findings

5. The level of available experience in applying the M\&E approach

A detailed description of each criterion and its relevance is provided in Table 18.1. Criteria 3-5 are rated on a 5 point scale (low, low to medium, medium, medium to high, high). The $M \& E$ approaches are rated relative to each other, i.e. if one is relatively more complex to carry out or leads to more subjective findings than another M\&E approach. 
Table 18.1 Decision support criteria to select M\&E approaches

\begin{tabular}{|c|c|c|}
\hline Criterion & Description & Relevance \\
\hline \multirow[t]{6}{*}{$\begin{array}{l}\text { Main intention/ } \\
\text { general } \\
\text { purpose }\end{array}$} & $\begin{array}{l}\text { Which of the three general purposes } \\
\text { (i) management, (ii) learning or (iii) } \\
\text { accountability an M\&E approach is } \\
\text { likely to predominantly address }\end{array}$ & \multirow{6}{*}{$\begin{array}{l}\text { It is important to consider the } \\
\text { intended use of an M\&E system at } \\
\text { the outset. This criterion helps users } \\
\text { determine whether a particular M\&E } \\
\text { approach has the potential to actually } \\
\text { meet the intended general purpose }\end{array}$} \\
\hline & $\begin{array}{l}\text { Management refers to supporting } \\
\text { the ongoing management of adapta- } \\
\text { tion actions and processes (in the } \\
\text { sense of adaptive management) }\end{array}$ & \\
\hline & $\begin{array}{l}\text { Learning refers to acquiring a } \\
\text { detailed understanding of how and } \\
\text { why adaptation interventions have } \\
\text { led to certain results or why they did } \\
\text { not achieve their objectives }\end{array}$ & \\
\hline & $\begin{array}{l}\text { Accountability refers to demon- } \\
\text { strating that processes and/or actions } \\
\text { have taken place and have led to } \\
\text { results }\end{array}$ & \\
\hline & $\begin{array}{l}\text { The nature of an approach, i.e. what } \\
\text { data and procedures it uses and what } \\
\text { information it provides, determines } \\
\text { which of the three general purposes it } \\
\text { can best support. For example, if a } \\
\text { small number of standard indicators } \\
\text { like "Number of beneficiaries" are } \\
\text { aggregated for a portfolio of adapta- } \\
\text { tion projects, the resulting informa- } \\
\text { tion is not adequate to infer how and } \\
\text { why adaptation has worked (Chen } \\
\text { and Uitto 2014). Thus, this approach } \\
\text { is most suitable for accountability } \\
\text { purposes, but not for learning }\end{array}$ & \\
\hline & $\begin{array}{l}\text { M\&E approaches can cater to more } \\
\text { than one general purpose depending } \\
\text { on how exactly they are designed in } \\
\text { practice }\end{array}$ & \\
\hline \multirow[t]{2}{*}{$\begin{array}{l}\text { Process or out- } \\
\text { come } \\
\text { orientation }\end{array}$} & $\begin{array}{l}\text { Whether the M\&E approach is } \\
\text { focusing more on the process of } \\
\text { implementation or on the outcomes } \\
\text { of adaptation }\end{array}$ & $\begin{array}{l}\text { The decision to monitor either pro- } \\
\text { cesses or outcomes, or both, influ- } \\
\text { ences the selection of suitable } \\
\text { approaches, because it entails differ- } \\
\text { ent requirements for M\&E }\end{array}$ \\
\hline & $\begin{array}{l}\text { This distinction is common in the } \\
\text { literature on adaptation M\&E since } \\
\text { assessing adaptation outcomes is } \\
\text { faced with various challenges (Bours } \\
\text { et al. 2014b). As a result, it was } \\
\text { suggested to initially focus on } \\
\text { process-based indicators and gradu- } \\
\text { ally move to outcome-based ones } \\
\text { (Harley et al. 2008) }\end{array}$ & $\begin{array}{l}\text { In the context of increasing levels of } \\
\text { climate finance it is particularly } \\
\text { important to outline which M\&E } \\
\text { approaches are actually capable of } \\
\text { assessing adaptation outcomes, and } \\
\text { which only focus on processes }\end{array}$ \\
\hline
\end{tabular}


Table 18.1 (continued)

\begin{tabular}{|c|c|c|}
\hline Criterion & Description & Relevance \\
\hline \multirow[t]{2}{*}{$\begin{array}{l}\text { Complexity of } \\
\text { implementation }\end{array}$} & $\begin{array}{l}\text { The relative complexity of an } \mathrm{M} \& \mathrm{E} \\
\text { approach compared to others. Low } \\
\text { complexity indicates that an } \mathrm{M} \& \mathrm{E} \\
\text { approach is relatively straight forward } \\
\text { to understand. For example, asking } \\
\text { beneficiaries about their perceptions } \\
\text { is an intuitively understood } \mathrm{M} \& \mathrm{E} \\
\text { procedure whereas the details of } \\
\text { assessing avoided economic costs are } \\
\text { more complex }\end{array}$ & \multirow[t]{2}{*}{$\begin{array}{l}\text { The degree of complexity provides a } \\
\text { rough indication of the ease of } \\
\text { applying an M\&E approach and of } \\
\text { the resources needed (know-how and } \\
\text { financial resources) }\end{array}$} \\
\hline & $\begin{array}{l}\text { Low complexity does not mean that } \\
\text { approaches can be easily } \\
\text { implemented. Qualitative assess- } \\
\text { ments also require relevant expertise } \\
\text { to be carried out in a rigorous manner }\end{array}$ & \\
\hline \multirow[t]{2}{*}{$\begin{array}{l}\text { Subjectivity of } \\
\text { resulting } \\
\text { information }\end{array}$} & $\begin{array}{l}\text { The relative subjectivity of the } \\
\text { resulting M\&E findings, i.e. the } \\
\text { extent to which they can be influenced } \\
\text { by those involved in the M\&E pro- } \\
\text { cess. For example, M\&E approaches } \\
\text { based on surveying beneficiaries will } \\
\text { be more subjective than impact eval- } \\
\text { uations based on quasi experimental } \\
\text { designs }\end{array}$ & \multirow[t]{2}{*}{$\begin{array}{l}\text { It is important to reflect how the } \\
\text { M\&E process can influence the } \\
\text { M\&E findings and how this reso- } \\
\text { nates with the purpose and intended } \\
\text { use of the M\&E results }\end{array}$} \\
\hline & $\begin{array}{l}\text { Subjectivity does not mean less } \\
\text { valuable information. In fact, the } \\
\text { views of beneficiaries or key infor- } \\
\text { mants may be exactly the type of } \\
\text { information needed. Moreover, } \\
\text { quantitative approaches cannot be } \\
\text { equated with objectivity. Whilst } \\
\text { indicator values may be objective, } \\
\text { the choice of which indictors are } \\
\text { included and how they are defined } \\
\text { may not be entirely objective }\end{array}$ & \\
\hline $\begin{array}{l}\text { Application } \\
\text { experience to } \\
\text { date }\end{array}$ & $\begin{array}{l}\text { Available experience to date in } \\
\text { applying a particular M\&E approach } \\
\text { to climate change adaptation. Some } \\
\text { approaches like theory of change or } \\
\text { those used for impact evaluations } \\
\text { have been widely used in other fields, } \\
\text { but this criterion focuses on the } \\
\text { available experience in applying them } \\
\text { specifically to adaptation to climate } \\
\text { change }\end{array}$ & $\begin{array}{l}\text { Available experience influences the } \\
\text { cost and uncertainty of applying a } \\
\text { particular M\&E approach }\end{array}$ \\
\hline
\end{tabular}

In addition to the five criteria, the Adaptation M\&E Navigator provides further details for every M\&E approach according to a template illustrated in Tables 18.3 and 18.4. The template provides information on the required human and financial resources to implement an $\mathrm{M} \& \mathrm{E}$ approach as well as on benefits and limitations. 
Since each M\&E approach can be implemented in a variety of ways, the descriptions are based on a general application and cannot take every possible variation into account. Corresponding to its nature as decision support tool, the Adaptation M\&E Navigator has to maintain a balance between level of detail and concise, easy to grasp information. Hence, it cannot provide comprehensive detail on how to carry out any of the listed M\&E approaches. For the latter purpose the template includes links to practical examples, guidance and further resources that users can refer to. Thus, the Adaptation M\&E Navigator equips decision makers and their technical advisors with an overview of relevant approaches and information to support the selection of an M\&E approach.

The core of the Adaptation M\&E Navigator is provided in Table 18.2 which connects specific purposes to relevant $M \& E$ approaches and shows their rating on the five criteria. In the online version of the Adaptation M\&E Navigator, colour codes are applied to facilitate a quick interpretation of the ratings. Tables 18.3 and 18.4

Table 18.2 The adaptation M\&E navigator: matching specific M\&E purposes to relevant $M \& E$ approaches

\begin{tabular}{|c|c|c|c|c|c|c|c|c|c|}
\hline$\#$ & \multicolumn{2}{|c|}{ Specific purpose } & \multicolumn{2}{|c|}{ M\&E approach } & General purpose & $\begin{array}{l}\text { Focus on } \\
\text { processes or } \\
\text { outcomes }\end{array}$ & $\begin{array}{l}\text { Com- } \\
\text { plexity }\end{array}$ & $\begin{array}{c}\text { Subjec- } \\
\text { tivity }\end{array}$ & $\begin{array}{c}\text { Ex- } \\
\text { perience }\end{array}$ \\
\hline 1 & \multirow{2}{*}{\multicolumn{2}{|c|}{$\begin{array}{l}\text { Monitoring the integration of } \\
\text { adaptation into planning } \\
\text { (mainstreaming) }\end{array}$}} & \multicolumn{2}{|c|}{$\begin{array}{l}\text { Qualitative assessment based on } \\
\text { interviews }\end{array}$} & Learning & $\mathrm{P}$ & L-M & $\mathrm{H}$ & M \\
\hline 1 & & & \multicolumn{2}{|c|}{ Quantitative or qualitative indicators } & $\begin{array}{l}\text { Management, } \\
\text { Accountability }\end{array}$ & $\mathrm{P}$ & L-M & L-M & M \\
\hline 2 & \multicolumn{2}{|c|}{$\begin{array}{l}\text { Monitoring the implementation of } \\
\text { adaptation programmes, projects or } \\
\text { actions }\end{array}$} & \multicolumn{2}{|c|}{$\begin{array}{l}\text { Defining and monitoring activities } \\
\text { and outputs }\end{array}$} & $\begin{array}{l}\text { Management, } \\
\text { Accountability }\end{array}$ & $\mathrm{P}$ & $\mathrm{L}$ & $\mathrm{L}$ & $\mathrm{H}$ \\
\hline 3 & \multicolumn{2}{|c|}{$\begin{array}{l}\text { Monitoring the implementation of } \\
\text { the National Adaptation Plan } \\
\text { process }\end{array}$} & \multicolumn{2}{|c|}{$\begin{array}{l}\text { Defining and monitoring milestones } \\
\text { in the NAP process }\end{array}$} & $\begin{array}{l}\text { Management, } \\
\text { Accountability }\end{array}$ & $\mathrm{P}$ & $\mathrm{L}$ & L-M & $\mathrm{L}$ \\
\hline 4 & \multicolumn{2}{|c|}{$\begin{array}{l}\text { Tracking adaptation activities at } \\
\text { national or sub-national level }\end{array}$} & \multicolumn{2}{|c|}{ Database of adaptation activities } & $\begin{array}{c}\text { Management, } \\
\text { Knowledge sharing }\end{array}$ & $\mathrm{P}$ & L-M & $\mathrm{M}^{\mathrm{a}}$ & L-M \\
\hline & \multirow{5}{*}{$\begin{array}{l}\text { Assessing the } \\
\text { results of } \\
\text { adaptation } \\
\text { projects or } \\
\text { actions }\end{array}$} & \multirow[t]{3}{*}{$\begin{array}{l}\text { On an ongoing or } \\
\text { repeated basis }\end{array}$} & \multicolumn{2}{|c|}{$\begin{array}{l}\text { Qualitative assessment involving } \\
\text { beneficiaries }\end{array}$} & Learning, Management & $\mathrm{P} / \mathrm{O}$ & L-M & $\mathrm{H}$ & M \\
\hline & & & \multicolumn{2}{|c|}{$\begin{array}{l}\text { Theory of change with adaptation- } \\
\text { specific indicators }\end{array}$} & $\begin{array}{l}\text { Management, } \\
\text { Accountability }\end{array}$ & $\mathrm{P} / \mathrm{O}$ & M & L-M & M \\
\hline 5 & & & \multicolumn{2}{|c|}{ Repeated vulnerability assessments } & \multicolumn{5}{|c|}{ See specific purpose \#7 } \\
\hline & & \multirow{2}{*}{$\begin{array}{l}\text { At a certain point } \\
\text { in time, typically } \\
\text { after completion }\end{array}$} & \multicolumn{2}{|c|}{ Impact evaluation } & Learning, Accountability & $\mathrm{O}$ & $\mathrm{H}$ & $\mathrm{L}$ & $\mathrm{L}$ \\
\hline & & & \multicolumn{2}{|c|}{$\begin{array}{l}\text { Assessing avoided economic losses } \\
\text { and health benefits }\end{array}$} & Accountability & $\mathrm{O}$ & $\mathrm{H}$ & $\mathrm{L}$ & $\mathrm{L}$ \\
\hline \multirow{2}{*}{6} & \multirow{2}{*}{\multicolumn{2}{|c|}{$\begin{array}{l}\text { Assessing the results of a } \\
\text { programme or portfolio of } \\
\text { adaptation projects }\end{array}$}} & \multicolumn{2}{|c|}{$\begin{array}{l}\text { Project-specific indicators informing } \\
\text { a synthesis of portfolio results }\end{array}$} & Accountability & $\mathrm{P} / \mathrm{O}$ & M & M & $\mathrm{L}$ \\
\hline & & & \multicolumn{2}{|c|}{$\begin{array}{l}\text { Common (core) indicators for every } \\
\text { project to enable aggregation }\end{array}$} & Accountability & $\mathrm{P} / \mathrm{O}$ & M & L-M & M \\
\hline & \multirow[t]{3}{*}{$\begin{array}{l}\text { Asses } \\
\text { been } 1 \\
\text { adapt: } \\
\text { action }\end{array}$} & $\begin{array}{l}\text { er vulnerability has } \\
\text { a result of } \\
\text { ammes, projects or }\end{array}$ & \multicolumn{2}{|c|}{$\begin{array}{l}\text { Measuring vulnerability with } \\
\text { indicators as part of a results-based } \\
\text { monitoring system }\end{array}$} & $\begin{array}{l}\text { Management, } \\
\text { Accountability }\end{array}$ & $\mathrm{O}$ & M & L-M & M \\
\hline 7 & & & \multirow{2}{*}{$\begin{array}{l}\text { Repeated } \\
\text { vulnerability } \\
\text { assessments }\end{array}$} & \begin{tabular}{l|l} 
Simple \\
\end{tabular} & Accountability & $\mathrm{O}$ & $\mathrm{L}$ & $\mathrm{H}$ & $\mathrm{M}-\mathrm{H}$ \\
\hline & & & & Data intensive & Learning, Accountability & $\mathrm{O}$ & M-H & L-M & $\mathrm{L}$ \\
\hline & \multirow{3}{*}{\multicolumn{2}{|c|}{$\begin{array}{l}\text { Assessing pr } \\
\text { adaptation go } \\
\text { outcomes at }\end{array}$}} & \multicolumn{2}{|c|}{$\begin{array}{l}\text { Qualitative assessment without } \\
\text { indicators }\end{array}$} & $\begin{array}{l}\text { Learning, Management, } \\
\text { Knowledge-sharing }\end{array}$ & $\mathrm{P} / \mathrm{O}$ & L-M & $\mathrm{M}-\mathrm{H}$ & $\mathrm{L}$ \\
\hline 8 & & & \multirow{2}{*}{$\begin{array}{l}\text { Indicator- } \\
\text { based } \\
\text { assessment }\end{array}$} & Trend indicators & Management & $\mathrm{P} / \mathrm{O}$ & M & $\mathrm{L}$ & L-M \\
\hline & & & & $\begin{array}{l}\text { Based on assumptions } \\
\text { about how activities } \\
\text { lead to outcomes }\end{array}$ & $\begin{array}{l}\text { Management, } \\
\text { Accountability }\end{array}$ & $\mathrm{P} / \mathrm{O}$ & M-H & L-M & L-M \\
\hline \multirow[b]{2}{*}{9} & \multirow{2}{*}{\multicolumn{2}{|c|}{$\begin{array}{l}\text { Assessing resilience to climate } \\
\text { change at national level }\end{array}$}} & \multicolumn{2}{|c|}{ Indicator-based assessments } & Management & $\mathrm{O}$ & M & L-M & L-M \\
\hline & & & \multicolumn{2}{|c|}{$\begin{array}{l}\text { Household level questions as part of } \\
\text { national census surveys }\end{array}$} & Management & $\mathrm{O}$ & M-H & $\mathrm{H}$ & $\mathrm{L}$ \\
\hline
\end{tabular}

Explanation: $\mathrm{L}=$ Low, $\mathrm{L}-\mathrm{M}=$ Low to Medium, $\mathrm{M}=$ Medium, $\mathrm{M}-\mathrm{H}=$ Medium to High, $\mathrm{H}=$ High; $\mathrm{P}=$ Process, $\mathrm{O}=$ Outcome, $\mathrm{P} / \mathrm{O}=$ Process and/or Outcome

aThe subjectivity lies in the decision what to count as "adaptation", i.e. what to include in the database of adaptation projects 
Table 18.3 Specific purpose: monitoring the integration of adaptation into planning (mainstreaming)

\begin{tabular}{|c|c|}
\hline \multicolumn{2}{|c|}{ Approach: qualitative assessment based on interviews } \\
\hline Prospect & $\begin{array}{l}\text { To provide in-depth understanding (learning) of the achievements and } \\
\text { shortcomings of the mainstreaming process }\end{array}$ \\
\hline $\begin{array}{l}\text { Potential use of M\&E } \\
\text { findings }\end{array}$ & $\begin{array}{l}\text { Results of the assessment could be used to improve the mainstreaming } \\
\text { process. The target audience includes those who carry out the } \\
\text { mainstreaming process and those who can influence it }\end{array}$ \\
\hline Description & $\begin{array}{l}\text { A qualitative assessment of the mechanism and degree of integration of } \\
\text { adaptation into planning processes (mainstreaming) and its effective- } \\
\text { ness based on interviews with key informants involved in and/or } \\
\text { affected by the implementation of the mainstreaming. Effectiveness } \\
\text { can be assessed by the extent to which climate change impacts are } \\
\text { taken into account in planning and decision making. A set of guiding } \\
\text { questions may be used for interviews }\end{array}$ \\
\hline $\begin{array}{l}\text { Benefits and } \\
\text { limitations }\end{array}$ & $\begin{array}{l}\text { Qualitative assessments can offer a more in-depth understanding than } \\
\text { quantitative indicators, particularly in regard to HOW and WHY things } \\
\text { work or do not work. Depending on the perspective, number and } \\
\text { composition of involved interviewees and on the exact assessment } \\
\text { procedures the results may differ in their comprehensiveness and } \\
\text { degree of subjectivity. Interviewees involved in the mainstreaming } \\
\text { may be hesitant to discuss shortcomings of the process }\end{array}$ \\
\hline Resources needed & $\begin{array}{l}\text { Qualified interviewers. Know-how to develop the assessment details. } \\
\text { Time and financial means to conduct a series of interviews }\end{array}$ \\
\hline $\begin{array}{l}\text { Example from } \\
\text { practice }\end{array}$ & $\begin{array}{l}\text { A study by GIZ (2016) examined the in-country coordination processes } \\
\text { for national adaptation planning in Jamaica, Togo and Kenya through } \\
\text { qualitative interviews. The results are meant to inform effective coor- } \\
\text { dination mechanisms which facilitate the integration of adaptation into } \\
\text { national planning and budgeting processes }\end{array}$ \\
\hline Links & $\begin{array}{l}\text { Preview of the study by GIZ (2016): http://www.napglobalnetwork. } \\
\text { org/wp-content/uploads/2016/03/sNAPshot-Jamaica-1.pdf }\end{array}$ \\
\hline
\end{tabular}

\section{Approach: quantitative indicators}

\begin{tabular}{l|l}
\hline Prospect & $\begin{array}{l}\text { To get quantitative expressions of the progress of integrating adapta- } \\
\text { tion into development planning }\end{array}$ \\
\hline $\begin{array}{l}\text { Potential use of M\&E } \\
\text { findings }\end{array}$ & $\begin{array}{l}\text { To track implementation and assess results for management and } \\
\text { accountability purposes }\end{array}$ \\
\hline Description & $\begin{array}{l}\text { An indicator-based assessment of selected aspects of the } \\
\text { mainstreaming process based on quantitative and/or qualitative infor- } \\
\text { mation. The criteria for scoring, i.e. what needs to be achieved to get a } \\
\text { certain indicator value, need to be clearly defined. This way, qualitative } \\
\text { information can be converted into quantitative scores }\end{array}$ \\
\hline $\begin{array}{l}\text { Benefits and } \\
\text { limitations }\end{array}$ & $\begin{array}{l}\text { Quantitative indicators can provide a snapshot of the status quo of the } \\
\text { mainstreaming process, albeit being limited to aspects which can be } \\
\text { more easily quantified. Quantitative indicators are not well suited to get } \\
\text { an in-depth understanding of how and why the mainstreaming process } \\
\text { works and where the shortcomings are }\end{array}$ \\
\hline Resources needed & $\begin{array}{l}\text { Resource requirements largely depend on the efforts needed to gather } \\
\text { the respective data and on the number of indicators. If the data can be } \\
\text { collected with relative ease then resource needs can be lower than for } \\
\text { qualitative assessments }\end{array}$ \\
\hline
\end{tabular}


Table 18.3 (continued)

\begin{tabular}{l|l}
\hline Examples from & $\begin{array}{l}\text { The Climate Investment Funds' Pilot Program for Climate Resilience } \\
\text { (PPCR) has operationalized the indicators "Degree of integration of } \\
\text { climate change in national, including sector, planning" and the "Evi- } \\
\text { dence of strengthened government capacity and coordination mecha- } \\
\text { nism to mainstream climate resilience" through scorecards (Röhrer and } \\
\text { Kouadio 2015). The indicators are specified through five sub-questions } \\
\text { which are measured at national level against criteria to be defined by } \\
\text { the national stakeholders }\end{array}$ \\
\hline $\begin{array}{l}\text { To assess the development of mainstreaming capacity of line ministries } \\
\text { executing the Government of Ethiopia's Climate-Resilient Green } \\
\text { Economy (CRGE) strategy a participatory self-assessment approach } \\
\text { was designed (Adler et al. 2015). An assessment matrix covering three } \\
\text { aspects of mainstreaming (planning, staff awareness and skills as well } \\
\text { as safeguards and equity) provides the scoring criteria. A qualified } \\
\text { assessor and the interviewees jointly agree on the score for each } \\
\text { component based on the assessment matrix }\end{array}$ & $\begin{array}{l}\text { IIED's Tracking Adaptation and Measuring Development (TAMD) } \\
\text { framework suggests indicators for climate risk management (track 1) } \\
\text { and for adaptation and development performance (track 2) based on a } \\
\text { theory of change. A number of generic indicators for track 1 have been } \\
\text { defined and can be assessed through scorecards (Brooks et al. 2014) }\end{array}$ \\
\hline $\begin{array}{l}\text { The Climate Investment Fund's website on measuring results: http:// } \\
\text { www.climateinvestmentfunds.org/cif/measuring-results }\end{array}$ \\
\hline $\begin{array}{l}\text { IIED's website on the Tracking Adaptation and Measuring Develop- } \\
\text { ment (TAMD) framework: http://www.iied.org/tracking-adaptation- } \\
\text { measuring-development-tamd }\end{array}$ \\
\hline $\begin{array}{l}\text { Repository of adaptation indicators: examples from national monitor- } \\
\text { ing and evaluation systems (Hammil et al. 2014b) }\end{array}$ \\
\hline Links & $\begin{array}{l}\text { and } \\
\text { and }\end{array}$ \\
\hline
\end{tabular}

Table 18.4 Specific purpose: monitoring the implementation of National Adaptation Plan process (NAP process)

Approach: defining and monitoring milestones in the NAP process

Background: The National Adaptation Plan (NAP) process was established by the parties to the UNFCCC to reduce vulnerability and integrate adaptation into policies and planning processes at all levels (UNFCCC 2011). The initial guidelines for the formulation of NAPs state that least developed country parties should "provide information in their national communications on the progress made and the effectiveness of the national adaptation plan process." (UNFCCC 2011, p. 86)

\begin{tabular}{l|l}
\hline Prospect & $\begin{array}{l}\text { Knowing whether the NAP process in a particular country is advancing } \\
\text { in accordance to predefined milestones or targets }\end{array}$ \\
\hline $\begin{array}{l}\text { Potential use of M\&E } \\
\text { findings }\end{array}$ & $\begin{array}{l}\text { To track the implementation of the NAP process for management and } \\
\text { accountability purposes }\end{array}$ \\
\hline Description & $\begin{array}{l}\text { Milestones or targets for the NAP process in a particular country are } \\
\text { defined and their achievement monitored at agreed points in time. The } \\
\text { milestones or targets need to be specific enough to enable an unam- } \\
\text { biguous assessment based on document analysis or interviews }\end{array}$ \\
\hline
\end{tabular}


Table 18.4 (continued)

\begin{tabular}{l|l}
\hline Approach: defining and monitoring milestones in the NAP process \\
\hline limitations & $\begin{array}{l}\text { Agreeing on milestones or targets for the NAP process can provide } \\
\text { orientation for its implementation. Comparing actual progress with } \\
\text { milestones does not directly provide an understanding of how and why } \\
\text { the mainstreaming process works or not, but it can indicate the need for } \\
\text { adjustments or further analysis }\end{array}$ \\
\hline Resources needed & $\begin{array}{l}\text { In general, resource requirements are low compared to other M\&E } \\
\text { approaches since some of the data is expected to be readily available } \\
\text { from document analysis }\end{array}$ \\
\hline practice & $\begin{array}{l}\text { The Least Developed Countries Expert Group (LEG) has defined ten } \\
\text { "Essential functions" that the NAP process should deliver to countries } \\
\text { (UNFCCC 2013). The NAP process can subsequently be monitored on } \\
\text { whether these functions are fulfilled in a given country. The LEG has } \\
\text { developed a tool for this purpose ("PEG tool") which defines expected } \\
\text { outcomes and a list of specific questions for each essential function }\end{array}$ \\
\hline $\begin{array}{l}\text { The Stocktaking for National Adaptation Planning (SNAP) tool by GIZ } \\
\text { (2014) defines seven success factors for the NAP process. Countries } \\
\text { can assess their current and intended future level on these success } \\
\text { factors. Progress over time can be illustrated in a radar chart (see GIZ } \\
\text { 2014) }\end{array}$ \\
\hline $\begin{array}{l}\text { Guidebook on the development of national adaptation M\&E systems } \\
\text { (Price-Kelly et al. 2015) }\end{array}$ \\
\hline $\begin{array}{l}\text { Website of the Least Developed Countries Expert Group (LEG) where } \\
\text { information on the PEG tool will be posted: http://unfccc.int/coopera } \\
\text { tion_support/least_developed_countries_portal/ldc_expert_group/ } \\
\text { items/6110.php }\end{array}$ \\
$\begin{array}{l}\text { Information on the NAP process including the SNAP tool: https://gc21. } \\
\text { giz.de/ibt/var/app/wp342deP/1443/index.php/knowledge/ } \\
\text { mainstreaming/ }\end{array}$ \\
\hline Links
\end{tabular}

showcase detailed descriptions of selected M\&E approaches. The complete version of the Adaptation M\&E Navigator including descriptions of all M\&E approaches is available on www.AdaptationCommunity.net under "Monitoring \& Evaluation" (see below).

\subsection{Using the Adaptation M\&E Navigator}

The Adaptation M\&E Navigator is available as online tool on www. AdaptationCommunity.net under "Monitoring \& Evaluation". Since early 2013, the knowledge portal AdaptationCommunity.net provides introductions to key topics, examples from practice, webinar recordings and publications on four focal topics including climate information, vulnerability assessment, mainstreaming and National Adaptation Planning as well as monitoring and evaluation. It is operated by GIZ (Deutsche Gesellschaft für Internationale Zusammenarbeit GmbH), the 
German technical development cooperation agency on behalf of the Federal Ministry for the Environment, Nature Conservation, Building and Nuclear Safety (BMUB) as well as the Federal Ministry for Economic Cooperation and Development (BMZ). Recently the topics of ecosystem-based adaptation and private sector adaptation have been added to the site. The website has so far reached the highest amount of users during the UNFCCC Conferences of the Parties and currently peaks at more than 2,000 accesses per day. Hosting the Adaptation M\&E Navigator on AdaptationCommunity.net not only ensures high accessibility and a relevant audience, but also enables updates of the tool as new experiences and publications become available.

\subsection{Limitations}

As a decision support tool, the Adaptation M\&E Navigator must be concise, easy to navigate, understandable to non-experts and applicable to a broad variety of contexts. It is therefore facing a number of tradeoffs. First, it has to strike a careful balance between being concise and providing sufficient degree of detail. As shown in Fig. 18.1, the scope of the Adaptation M\&E Navigator is limited to providing an overview of relevant approaches in form of a brief description. Additional guidance may be needed to design and implement a particular approach. Second, in order to keep the approaches to a manageable number they have to be applicable to a relatively broad context and cannot account for every possible variation. As a result, the ratings provided for the three criteria of complexity, subjectivity and available experience are indicative only and could deviate in practice depending on the details of implementation. Third, some of the specific M\&E purposes are more suited to standardized M\&E approaches than others. Practice has shown that national adaptation $M \& E$ systems developed to date are diverse and very context dependent (EEA 2015; Hammil et al. 2014a; Leiter 2013). Thus, whilst the Adaptation M\&E Navigator can point to a direction in regard to a suitable M\&E approach, the development of the actual M\&E system may require a more complex process (considerations for developing national adaptation $M \& E$ systems are outlined in Leiter (2013) and Price-Kelly et al. (2015)).

Furthermore, whilst there was general agreement on the common M\&E purposes featured in the Adaptation M\&E Navigator, feedback by colleagues who commented on a draft version suggests that the purposes could be arranged in slightly different ways. For instance, if monitoring the implementation of projects (purpose \#2) was broadened to include monitoring of adaptation plans, then monitoring the National Adaptation Plan process (purpose \#3) could be grouped as a special case under it. Nevertheless, it was maintained as a separate item due to its importance for countries under the UNFCCC negotiations. Finally, as pointed out by Fisher et al. (2015, p. 30): "What makes a method most appropriate to climate change adaptation is not necessarily its intrinsic qualities, (...), but instead how the method is applied." Thus, the decision support provided by the Adaptation M\&E Navigator is only part of the total process that leads to an effective application of M\&E for adaptation to climate change (compare Fig. 18.1). 


\subsection{Conclusion}

The Adaptation M\&E Navigator is closing a gap in the existing landscape of guidebooks and tools for adaptation M\&E. First, it provides a list of specific purposes for undertaking adaptation $M \& E$ in practice. In doing so it goes beyond the frequently stated general purposes like accountability and learning which, taken on their own, are not sufficient to decide upon particular M\&E approaches. Secondly, the Adaptation M\&E Navigator illustrates to decision makers the range of available options and equips them with the necessary information to select among those the most suitable one for their particular purpose. The Adaptation M\&E Navigator is hosted on an established online platform (www. AdaptationCommunity.net) in the form of an easy to use web interface. By drawing upon adaptation $M \& E$ approaches and examples available to date, the Adaptation M\&E Navigator also demonstrates the progress which has been made in this subject area since the first International Conference on Evaluating Climate Change and Development took place in 2009.

\section{References}

Adler, R., Wilson, K., Abbot, P., \& Blackshaw, U. (2015). Approach to monitoring and evaluation of institutional capacity for adaptation to climate change: The case of the United Kingdom's investment to Ethiopia's climate-resilient green economy. In D. Bours, C. McGinn, \& P. Pringle (Eds.), Monitoring and evaluation of climate change adaptation: A review of the landscape. New Directions for Evaluation, 147, 61-74.

Bours, D., McGinn, C., \& Pringle, P. (2014a). Monitoring \& evaluation for climate change adaptation and resilience: A synthesis of tools, frameworks and approaches (2nd ed.). Phnom Penh: SEA Change Community of Practice, and Oxford UKCIP. Retrieved from: http://www.seachangecop.org/node/3258

Bours, D., McGinn, C., \& Pringle, P. (2014b). Guidance note 1: Twelve reasons why climate change adaptation $M \& E$ is challenging. Phnom Penh: SEA Change CoP, and Oxford, United Kingdom: UKCIP. Retrieved from http://www.ukcip.org.uk/wp-content/PDFs/MandE-Guid ance-Note1.pdf.

Brooks, N., Anderson, S., Ayers, J., Burton, I., \& Tellam, I. (2011). Tracking adaptation and measuring development (TAMD) (Climate ChangeWorking Paper No. 1). London: International Institute for Environmental Development (IIED). Retrieved from http://pubs.iied.org/ pdfs/10031IIED.pdf

Brooks, N., Fisher, S., Rai, N., Anderson, S., Karani, I., Levine, T., \& Steinbach, D. (2014). Tracking adaptation and measuring development. A step-by-step guide. London: International Institute for Environmental Development (IIED). Retrieved from http://pubs.iied.org/ 10100IIED.html

CARE. (2012). Participatory monitoring, evaluation, reflection and learning for community-based adaptation: A manual for local practitioners. CARE International and IIED. Retrieved from: http://www.care.org/sites/default/files/documents/CC-2012-CARE_PMERL_Manual_2012.pdf

Chen, S., \& Uitto, J. I. (2014). Small grants, big impacts. Aggregation challenges. In J. I. Uitto (Ed.), Evaluating environment in international development (pp. 105-122). New York: Routledge.

European Environment Agency (EEA). (2015). National monitoring, reporting and evaluation of climate change adaptation in Europe. Copenhagen: European Environment Agency (EEA). 
Fisher, S., Dinshaw, A., McGray, H., Rai, N., \& Schaar, J. (2015). Evaluating climate change adaptation: Learning from methods in international development. In D. Bours, C. McGinn, \& P. Pringle (Eds.), Monitoring and evaluation of climate change adaptation: A review of the landscape. New Directions for Evaluation, 147, 13-35.

Ford, J. D., Berrang-Ford, L., Lesnikowski, A., Barrera, M., \& Heymann, S. J. (2013). How to track adaptation to climate change: A typology of approaches for national-level application. Ecology and Society, 18(3), 40.

Fritzsche, K., Schneiderbauer, S., Bubeck, P., Kienberger, S., Buth, M., Zebisch, M., \& Kahlenborn, W. (2014). The vulnerability sourcebook. Concept and guidelines for standardised vulnerability assessments. Eschborn: Deutsche Gesellschaft für Internationale Zusammenarbeit (GIZ) GmbH. Retrieved from http://www.adaptationcommunity.net/knowl edge/vulnerability-assessment/vulnerability-sourcebook/

GIZ. (2014). The stocktaking for National Adaptation Planning (SNAP) tool. Eschborn: Deutsche Gesellschaft für Internationale Zusammenarbeit (GIZ) GmbH. Retrieved from http://www. adaptationcommunity.net/?wpfb_dl=148

GIZ. (2016). Institutional context analyses for national climate adaptation planning processes: Lessons from Jamaica, Kenya and Togo. Eschborn: Deutsche Gesellschaft für Internationale Zusammenarbeit (GIZ) GmbH.

Hammil, A., Dekens, J., Olivier, J., Leiter, T., \& Klockemann, L. (2014a). Monitoring and evaluating adaptation at aggregated levels: A comparative analysis of ten systems. Eschborn: Deutsche Gesellschaft für Internationale Zusammenarbeit (GIZ) GmbH. Retrieved from http:// www.adaptationcommunity.net/knowledge/monitoring-evaluation-2/national-level-adaptationme/overview-and-analysis-of-10-nationaladaptation-systems/

Hammil, A., Dekens, J., Leiter, T., Olivier, J., \& Klockemann, L. (2014b). Repository of adaptation indicators. Real case examples from national monitoring and evaluation systems. Eschborn: Deutsche Gesellschaft für Internationale Zusammenarbeit (GIZ) GmbH. Retrieved from http://www.adaptationcommunity.net/knowledge/monitoring-evaluation-2/nationallevel-adaptation-me/repository-of-adaptation-ndicators/

Harley, M., Horrocks, L., Hodgson, N., \& Van Minnen, J. (2008). Climate change vulnerability and adaptation indicators (ETC/ACC Technical Paper 2008/9). Bilthoven: European Topic Centre on Air and Climate Change, European Environmental Agency.

Leiter, T. (2013). Recommendations for adaptation $M \& E$ in practice. Discussion paper. Eschborn: Deutsche Gesellschaft für Internationale Zusammenarbeit (GIZ) GmbH. Retrieved from: http://www.adaptationcommunity.net/?wpfb_dl=132

Leiter, T. (2015). Linking monitoring and evaluation of adaptation to climate change across scales: Avenues and practical approaches. In D. Bours, C. McGinn, \& P. Pringle (Eds.), Monitoring and evaluation of climate change adaptation: A review of the landscape. New Directions for Evaluation, 147, 117-127.

Mimura, N., Pulwarty, R. S., Duc, D. M., Elshinnawy, I., Redsteer, M. H., Huang, H. Q., Nkem, J. N., \& Sanchez Rodriguez, R. A. (2014). Adaptation planning and implementation. In C. B. Field, V. R. Barros, D. J. Dokken, K. J. Mach, M. D. Mastrandrea, T. E. Bilir, M. Chatterjee, K. L. Ebi, Y. O. Estrada, R. C. Genova, B. Girma, E. S. Kissel, A. N. Levy, S. MacCracken, P. R. Mastrandrea, \& L. L. White (Eds.), Climate change 2014: Impacts, adaptation, and vulnerability. Part A: Global and sectoral aspects. Contribution of Working Group II to the Fifth Assessment Report of the Intergovernmental Panel on Climate Change. Cambridge: Cambridge University Press.

Nachmany, M., Frankhauser, S., Davidova, J., Kingsmill, N., Landesman, T., Roppongi, H., ...Townshend, T. (2015). The 2015 global climate legislation study. A review of climate change legislation in 99 countries. London: Grantham Research Institute on Climate Change and the Environment.

OECD Development Assistance Committee (OECD-DAC). (2015). Climate-related development finance in 2013. Retrieved from: http://www.oecd.org/dac/environment-development/Climaterelated\%20development\%20finance_June\%202015.pdf

Olivier, J., Leiter, T., \& Linke, J. (2013). Adaptation made to measure: A guidebook to the design and results-based monitoring of climate change adaptation projects ( $2 \mathrm{nd}$ ed.). Eschborn: 
Deutsche Gesellschaft für Internationale Zusammenarbeit (GIZ) GmbH. Retrieved from http:// www.adaptationcommunity.net/knowledge/monitoring-evaluation-2/project-level-adapta tion-me-2/adaptation-made-to-measure/

Price-Kelly, H., Leiter, T., Olivier, J., \& Hammil, A. (2015). Developing national adaptation monitoring and evaluation systems: A guidebook. Eschborn: Deutsche Gesellschaft für Internationale Zusammenarbeit (GIZ) GmbH. Retrieved from http://www. adaptationcommunity.net/knowledge/monitoring-evaluation-2/national-level-adaptation-me/ developing-national-adaptation-me-systems/

Pringle, P. (2011). AdaptME toolkit: Adaptation monitoring and evaluation. Oxford, UK: UKCIP. Retrieved from: http://www.ukcip.org.uk/wp-content/PDFs/UKCIP-AdaptME.pdf

PROVIA. (2013). PROVIA guidance on assessing vulnerability, impacts and adaptation to climate change. Published by the United Nations Environment Programme (UNEP). Retrieved from: http://www.unep.org/provia/RESOURCES/Publications/PROVIAGuidancereport/tabid/130752/ Default.aspx

Röhrer, C., \& Kouadio, K. E. (2015). Monitoring, reporting, and evidence-based learning in the climate investment fund's pilot program for climate resilience. In D. Bours, C. McGinn, \& P. Pringle (Eds.), Monitoring and evaluation of climate change adaptation: A review of the landscape. New Directions for Evaluation, 147, 129-145.

Spearman, M., \& McGray, H. (2011). Making adaptation count: Concepts and options for monitoring and evaluation of climate change adaptation. Eschborn: Gesellschaft für Internationale Zusammenarbeit (GIZ) GmbH. Retrieved from http://pdf.wri.org/making_adap tation_count.pdf

Terpstra, P., \& Peterson-Carvalho, A. (2015). Tracking adaptation finance. An approach for civil society organizations to improve accountability for climate change. Washington, DC: World Resources Institute, and Oxfam America. Retrieved from: http://www.wri.org/publication/ tracking-adaptation-finance

United Nations Framework Convention on Climate Change (UNFCCC). (2011). Report of the conference of the parties on its seventeenth session (Addendum Part Two: Action taken by the Conference of the Parties at its seventeenth session. FCCC/CP/2011/9/Add.1). Bonn: United Nations Framework Convention on Climate Change.

United Nations Framework Convention on Climate Change (UNFCCC). (2013). Report on the 24th meeting of the Least Developed Countries Expert Group (FCCC/SBI/2013/15). Bonn: United Nations Framework Convention on Climate Change.

Welle, T., Witting, M., Birkmann, J., \& Brossmann, M. (2014). Assessing and monitoring climate resilience. From theoretical considerations to practically applicable tools - a discussion paper. Eschborn: Deutsche Gesellschaft für Internationale Zusammenarbeit (GIZ) GmbH. Retrieved from http://www.adaptationcommunity.net/knowledge/monitoring-evaluation-2/ national-level-adaptation-me/ssessing-and-monitoring-climate-resilience/

Open Access This chapter is distributed under the terms of the Creative Commons AttributionNonCommercial 4.0 International License (http://creativecommons.org/licenses/by-nc/4.0/), which permits any noncommercial use, duplication, adaptation, distribution and reproduction in any medium or format, as long as you give appropriate credit to the original author(s) and the source, provide a link to the Creative Commons license and indicate if changes were made.

The images or other third party material in this chapter are included in the work's Creative Commons license, unless indicated otherwise in the credit line; if such material is not included in the work's Creative Commons license and the respective action is not permitted by statutory regulation, users will need to obtain permission from the license holder to duplicate, adapt or reproduce the material.

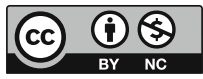

